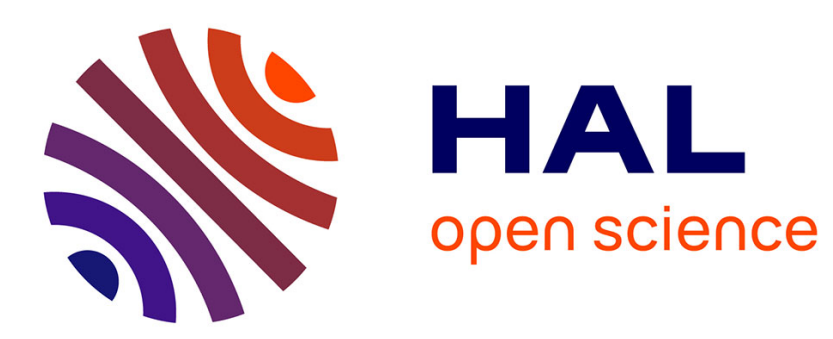

\title{
Regulation of glycolysis and cancer cell proliferation by PKM2 citrullination
}

Sébastien Coassolo, Irwin Davidson

\section{To cite this version:}

Sébastien Coassolo, Irwin Davidson. Regulation of glycolysis and cancer cell proliferation by PKM2 citrullination. Molecular \& Cellular Oncology, 2021, 8 (4), 10.1080/23723556.2021.1927446 . hal03442215

\section{HAL Id: hal-03442215 \\ https://hal.science/hal-03442215}

Submitted on 23 Nov 2021

HAL is a multi-disciplinary open access archive for the deposit and dissemination of scientific research documents, whether they are published or not. The documents may come from teaching and research institutions in France or abroad, or from public or private research centers.
L'archive ouverte pluridisciplinaire HAL, est destinée au dépôt et à la diffusion de documents scientifiques de niveau recherche, publiés ou non, émanant des établissements d'enseignement et de recherche français ou étrangers, des laboratoires publics ou privés. 
archives-ouvertes

\title{
Regulation of glycolysis and cancer cell proliferation by PKM2 citrullination
}

\author{
Sébastien Coassolo, Irwin Davidson
}

\section{To cite this version:}

Sébastien Coassolo, Irwin Davidson. Regulation of glycolysis and cancer cell proliferation by PKM2 citrullination. Molecular \& Cellular Oncology, Taylor et Francis, 2021, 8 (4), 10.1080/23723556.2021.1927446 . hal-03442215

\section{HAL Id: hal-03442215 \\ https://hal.archives-ouvertes.fr/hal-03442215}

Submitted on 23 Nov 2021

HAL is a multi-disciplinary open access archive for the deposit and dissemination of scientific research documents, whether they are published or not. The documents may come from teaching and research institutions in France or abroad, or from public or private research centers.
L'archive ouverte pluridisciplinaire HAL, est destinée au dépôt et à la diffusion de documents scientifiques de niveau recherche, publiés ou non, émanant des établissements d'enseignement et de recherche français ou étrangers, des laboratoires publics ou privés. 


\section{Regulation of glycolysis and cancer cell proliferation by PKM2 citrullination.}

Sébastien Coassolo ${ }^{1,2,3,4,5}$, and Irwin Davidson ${ }^{1,2,3,4,6}$.

1. Institut de Génétique et de Biologie Moléculaire et Cellulaire, Equipe Labélisée Ligue contre le Cancer. 67404 Illkirch Cedex, France

2. Centre National de la Recherche Scientifique, UMR7104.

3. Institut National de la Santé et de la Recherche Médicale, U1258.

4. Université de Strasbourg.

5. Current address: Discovery Oncology, Genentech, South San Francisco, CA 94080, USA.

6. To whom correspondence should be addressed

E mail : irwin@igbmc.fr

Running Title : PKM2 citrullination regulates glycolysis

Key words : NuRD complex, chromatin, melanoma, protein arginine deiminase, allosteric regulation.

The Authors declare no competing interests. 


\begin{abstract}
Conversion of peptidyl-arginine to peptidyl citrulline, known as citrullination, is a posttranslational protein modification catalysed by the PADI (Protein Arginine Deiminase) family of enzymes. PADI1 and PADI3 catalyse citrullination of arginine 106 in the glycolytic enzyme pyruvate kinase M2 modulating its allosteric regulation, glycolysis and cancer cell proliferation.
\end{abstract}


extended network of hydrogen bonds within the pocket. Consequently, R106 citrullination should reduce inhibition by Trp/Phe/Ala allowing PKM2 to remain active even under limiting Ser concentrations leading to excessive glycolysis and reduced anabolic capacity detrimental for cell growth. Indeed, synthetic small molecules that activate PKM2 stimulate glycolysis resulting in Ser auxotrophy and reduced cell proliferation ${ }^{6}$. We confirmed this idea by real time measure of glycolysis in living cells and of PKM2 enzymatic activity in presence of increasing exogenous Trp/Phe/Ala. Ectopic PAD1 and PAD3 expression partially overcame Trp/Phe/Ala-induced repression of PKM2 activity leading to increased glycolysis, diminished ATP levels and reduced cell proliferation (Fig. 1). Strikingly therefore, this subtle post translational modification of PKM2 R106 leading to diminished hydrogen bonding capacity translated into a major impact on cellular metabolism and proliferation of melanoma, renal cell carcinoma, breast and cervical carcinoma cells.

The key step in this pathway is regulation of expression of the PADII and PADI3 genes that encode the PAD1 and PAD3 enzymes, respectively. In our recent study, we found that PADI1 and PADI3 were repressed by Chromodomain helicase DNA binding protein 4 (CHD4); the catalytic ATPase subunit of the Nucleosome Remodelling and Deacetylation (NuRD) complex, an epigenetic regulator of gene expression, acting mainly as a co-repressor ${ }^{7}$. SiRNAmediated CHD4 knockdown in multiple cancer cell types de-repressed PADI1 and PADI3 expression, stimulating glycolysis and PKM2 enzymatic activity analogous to ectopic PAD1 and PAD3 expression. These observations therefore define a novel link between the epigenetic regulation of PAD1 and PAD3 expression, PKM2 citrullination, glycolysis and cancer cell proliferation.

As described above, the near stoichiometric conversion of glucose to lactate is a hallmark of cancer cells grown in culture that is impacted by PKM2 citrullination. In tumours in vivo however, mitochondrial metabolism involving the tricarboxylic acid cycle (TCA) cycle 
and oxidative phosphorylation are also essential for production of ATP and important metabolites ${ }^{8}$. To address the role PKM2 citrullination may play in vivo, we analysed PADI1 and PADI3 expression in the TCGA (The Cancer Genome Atlas) database showing they were most expressed in solid tumours like bladder, pancreatic, cervical, head and neck and clear cell renal cancers with known hypoxic character. Moreover, PADI1 and PADI3 expression positively correlated with the patient hypoxic signature of pancreatic adenocarcinoma, clear cell renal cancers, and lung adenocarcinoma. Regulation by hypoxia was experimentally confirmed by growth of melanoma cells in hypoxic or pseudo-hypoxic conditions in vitro where increased PAD1 and PAD3 expression catalyzed PKM2 R106 citrullination contributing to the increased glycolysis. Hypoxia therefore seems to regulate PKM2 activity by proline hydroxylation ${ }^{9}$ and by citrullination both of which contribute to increased glycolysis. PAD enzyme expression is also de-regulated in other pathological situations characterised by hypoxia such as rheumatoid arthritis (RA). Thus, PAD1 and PAD3 expression and PKM2 citrullination seen in RA ${ }^{10}$ may account for the increased glycolysis seen in activated RAassociated fibroblast-like synoviocytes.

In conclusion, we defined a novel pathway where epigenetic and/or hypoxia-mediated regulation of PAD1 and PAD3 expression modulates PKM2 citrullination, glycolysis and cancer cell proliferation.

\section{Disclosure of potential conflicts of interest}

The Authors declare no competing interests. 
Funding. This work was supported by institutional grants from the Centre National de la Recherche Scientifique, the Institut National de la Santé et de la Recherche Médicale, the Université de Strasbourg, the Association pour la Recherche contre le Cancer (CR, contract number PJA 20181208268), the Ligue Nationale contre le Cancer, the Institut National du Cancer, the ANR-10-LABX-0030-INRT French state fund through the Agence Nationale de la Recherche under the frame programme Investissements d'Avenir labelled ANR-10-IDEX0002-02. ID is an 'équipe labellisée’ of the Ligue Nationale contre le Cancer. SC was supported by a fellowship from the Ligue Nationale contre le Cancer.

\section{References}

1. Hanahan, D. \& Weinberg, R. A. Hallmarks of cancer: the next generation. Cell 144, 646-74 (2011).

2. Dayton, T. L., Jacks, T. \& Vander Heiden, M. G. PKM2, cancer metabolism, and the road ahead. EMBO Rep 17, 1721-1730 (2016).

3. Yuan, M. et al. An allostatic mechanism for M2 pyruvate kinase as an amino-acid sensor. Biochem J 475, 1821-1837 (2018).

4. Coassolo, S. et al. Citrullination of pyruvate kinase M2 by PADI1 and PADI3 regulates glycolysis and cancer cell proliferation. Nat Commun 12, 1718 (2021).

5. Mondal, S. \& Thompson, P. R. Chemical biology of protein citrullination by the protein A arginine deiminases. Curr Opin Chem Biol 63, 19-27 (2021).

6. Kung, C. et al. Small molecule activation of PKM2 in cancer cells induces serine auxotrophy. Chem Biol 19, 1187-98 (2012). 
7. Bornelov, S. et al. The Nucleosome Remodeling and Deacetylation Complex Modulates Chromatin Structure at Sites of Active Transcription to Fine-Tune Gene Expression. Mol Cell 71, 56-72 e4 (2018).

8. Vander Heiden, M. G. \& DeBerardinis, R. J. Understanding the Intersections between Metabolism and Cancer Biology. Cell 168, 657-669 (2017).

9. Luo, W. et al. Pyruvate kinase M2 is a PHD3-stimulated coactivator for hypoxia-inducible factor 1. Cell 145, 732-44 (2011).

10. Tilvawala, R. et al. The Rheumatoid Arthritis-Associated Citrullinome. Cell Chem Biol 25, 691-704 e6 (2018).

\section{Legend to Figure}

Regulation of glycolysis by PKM2 citrullination. When present at high levels, Serine (Ser) activates pyruvate kinase M2 (PKM2; represented as a tetramer) assuring glycolysis, Adenosine TriPhosphate (ATP) production and proliferation. When Ser levels are lowered, PKM2 activity is reduced by binding of Tryptophan/Phenylalanine/Alanine (Trp/Phe/Ala) leading to reduced glycolysis. When PAD1 (protein arginine deiminase) and PAD3 are up-regulated by hypoxia or other epigenetic mechanisms, PKM2 citrullination reduces the inhibitory potential of Trp/Phe/Ala maintaining glycolysis under limiting Ser conditions and reducing the availability of glycolytic metabolites for anabolic processes. In addition, excessive pyruvate conversion to lactate limits the tricarboxylic acid cycle cycle leading to reduced ATP levels and diminished proliferation. 
Hypoxia/

epigenetic regulation

$$
\text { - }
$$

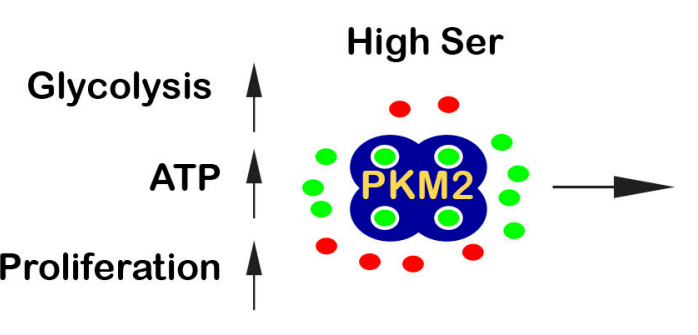

Low Ser

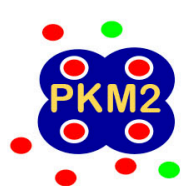

-

Proliferation
Limiting Ser

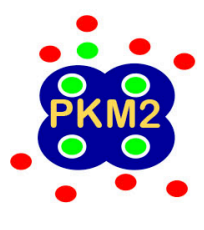

Glycolysis ATP

\section{Citrullination}
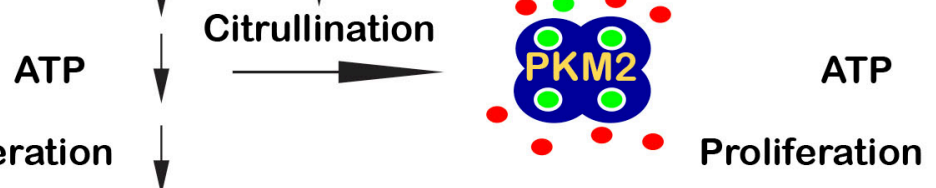